заведений; беседы с учителями музыкального искусства. Определены направления модернизации профессиональной подготовки будущих учителей музыкального искусства к вокально-педагогической деятельности.

Ключевые слова: вокально-педагогчческая деятельность; профессиональная подготовка; учитель музыкального искусства.

\title{
MODERN SITUATIONS OF TRAINING OF FUTURE TEACHERS OF MUSIC ART TO VOCAL AND EDUCATIONAL ACTIVITIES
}

\author{
Ovcharenko Natalia, Doctor of Pedagogical Sciences, associate professor, Kryvyi Rig State Pedagogical \\ University, 54-a Gagarina Str., 50086, Kryvyi Rig, , Ukraine, shvager77@gmail.com
}

\begin{abstract}
The article highlights the results of a study of the current state of training of future teachers of music to vocal and educational activities. The research is based on the analyses of regulation documents that underpin the training of future teachers of music to vocal and educational activities: State industry standard, educational qualification characteristics and educational and professional training programs, curricula and training programs for future teachers of music. According to the survey of students of art higher educational institutions author studied music teachers opinion on training graduate of the Faculty of Arts for vocal and educational activities and problems that arise during the adaptation of young specialists in general secondary institution. The following directions of modernization of training future teachers of music to vocal and educational activities have been found, as consideration in preparing the content structure of a multi-vocal teacher of teachers of music; realization competence approach for vocational training; implementing highly, multi-style and multi-genre repertoire according to the chosen style of singing; the use of educational material for indepth analysis of vocal works and better understanding and interpretation of performance; study and implementation of international experience improving the quality of training of future teachers of music to vocal and educational activities.

Keywords: future teacher on music art; professional training; vocal and educational activities.
\end{abstract}

Стаття надійшла до редакції 20.09.2016 Прийнято до друку 27.10.2016

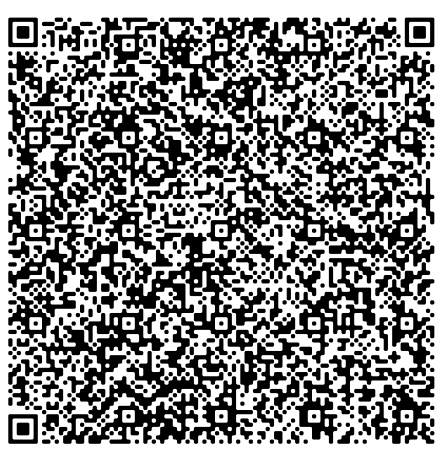

УДК $378.048 .2: 614.23$

Олександра Лисенко ORCID iD 0000-0001-9356-1306

кандидат педагогічних наук, заступник директора Інституту післядипломної освіти, Національний медичний університет імені О. О. Богомольця, бульвар Т. Шевченка, 13, 01601 м. Київ, Україна A.Yu.Lysenko@gmail.com

\section{ІГРОВІ КОМП'ЮТЕРНІ ПЛАТФОРМИ ЯК ЗАСІБ КОНТРОЛЮ У ПРОЦЕСІ ПІДГОТОВКИ ЛІКАРІВ-ІНТЕРНІВ}

\begin{abstract}
У запропонованій статті розглянуто необхідність здійснення контролю, як форми зворотного зв'язку на післядипломному етапі підготовки лікарів; визначено особливості, притаманні післядипломному етапу підготовки лікарів, що мають бути враховані при забезпеченні належного контролю їх навчальної діяльності; окреслено необхідність застосування інформаційно-комунікативних технологій дистанційного навчання, зокрема ігрових комп'ютерних платформ для налагодження зворотного зв'язку, проведення проміжного оцінювання засвоєних знань, а також створення підгрунття для дискусї.
\end{abstract}

Ключові слова: зворотній зв'язок; ігрові комп'ютерні платформи; інформачійно-комунікативні технології.

Вступ. Сучасний стан соціальних та економічних перетворень, що відбуваються у нас в державі обумовлює необхідність щодо оновлення й удосконалення існуючої системи підготовки фахівців 3 урахуванням процесів, властивих культурній глобалізації. Відтак, все більш актуальним постає питання підготовки конкурентоспроможного людського капіталу, здатного до інноваційного розвитку країни, особистої самореалізації та задоволення суспільних потреб.

Слід зазначити, що обов'язковою передумовою описаних позитивних зрушень є налагодження ефективного науково обгрунтованого процесу управління освітньою системою, адже саме менедж- 
мент є рушійним процесом у досягненні успіху у діяльності будь-якої організації, системи тощо.

Практика управління є досить стародавньою, так як навіть доісторичні люди жили організованими групами, у яких здійснювалися управлінські функції задля отримання більш високих результатів своєї діяльності. Основним поштовхом до розвитку управління як науки була промислова революція розвиток виробництва, створення підприємств, налагодження роботи у колективі тощо. У XX ст. управління виокремилося в окрему самостійну науку - менеджмент, що було визнано з публікацією книги Ф. У. Тейлора «Принципи наукового управління» (Тейлор Ф.У., 1992, с. 12).

Сьогодні процесний менеджмент являє собою складне та комплексне утворення на розвиток якого мали вплив чотири підходи: з позиції виділення різних шкіл, процесний, системний і ситуаційний. Водночас, управлінська діяльність має ряд загальних характеристик, знання та розуміння яких може допомогти керівнику, як управлінцю досягти поставлених цілей. На думку професора Генрі Мінцберга, даний процес передбачає реалізацію міжособистісних, інформаційних ролей, а також таких, що безпосередньо пов'язані з прийняттям рішення (Мінцберг Г., 2004, с. 48). Успішне управління системою післядипломної підготовки лікарів - процес, що поєднує в собі впровадження загальних основ менеджменту та розуміння особливостей професійного становлення лікарів.

Мета статті - обгрунтувати доцільність застосування інформаційно-комунікативних технології дистанційного навчання як засобу налагодження ефективного зворотного зв'язку 3 лікарями-інтернами.

Результати та іх обговорення. Розглядаючи освітню систему як самостійний організаційний процес, звертаємо увагу на інформаційну управлінську роль, що передбачає отримання, розповсюдження та представлення інформації, зокрема шляхом налагодження ефективної комунікації між учасниками процесу (Мінцберг Г., 2004, с. 49).

Однією з важливих умов ефективної комунікації $є$ налагодження поміж його учасниками зворотного зв’язку, що являє собою процес обміну змістовою та оціночною реакціями партнерів на інформацію та поведінку один одного (Василинка М. А., 2006, с. 143).

В умовах організації навчального процесу однією з необхідних обов'язкових форм зворотного зв'язку постає контроль. Контроль - функція управління, що базується на спостереженні та перевірці відповідності процесу функціонування та фактичного стану організації установленим вимогам з метою виявлення відхилень і своєчасної їх ліквідаціï. Такий вид зворотного зв'язку спрямований на учнів виконує оціночну, коректувальну та мотиваційно-стимулюючу функції (Савченко О. Я., 1997, c. 124). Саме тому, належна організація контролю, що здійснюватиметься на постійній основі є одні- єю з обов’язкових умов ефективного управління навчальним процесом.

Слід зазначити, що належна організація контролю, як форми зворотного зв'язку може бути здійснена лише з урахуванням особливостей структури самого навчального процесу (Зварич I., 2000, с. 44).

Так, розглядаючи систему післядипломної підготовки лікарів на прикладі інтернатури, ми маємо врахувати певні структурні особливості цього процесу, зокрема:

- $\quad$ практичну спрямованість;

- черговість очної та заочної частин навчання;

- особистість дорослого учня.

Проаналізуємо зазначені особливості крізь призму налагодження ефективного зворотного зв'язку у формі контролю.

Інтернатура, як обов'язкова форма післядипломної освіти передбачає підвищення рівня практичної підготовки випускників вищих медичних навчальних закладів і проводиться в очно-заочній формі навчання. Очна частина підготовки проводиться на кафедрах вищих медичних навчальних закладів і передбачає аудиторну підготовку у формі лекційних практичних і семінарських занять. Заочна частина відбувається у формі стажування на базах закладів охорони здоров’я. Тривалість очної та заочної частин підготовки є відмінною для різних спеціальностей, так для хірургічного фаху загальна тривалість підготовки в інтернатурі становить 33 місяці, з них на заочну частину, під час якої лікар-інтерн самостійно провадить практичну діяльність під контролем досвідчених колег (лікарів вищої / першої кваліфікаційної категорії), припадає 21 місяць, що становить 63,6\% загальної тривалості первинної спеціалізації. Для лікарів-інтернів терапевтичного профілю співвідношення практичної та теоретичної частин підготовки становить, в середньому, 1:1 (Наказ МОЗ України №291 від 19 вересня 1996 р.).

Таким чином, тривалість заочної частини навчання під час якої лікарі-інтерни знаходяться на базі закладу охорони здоров'я є досить тривалою, що відповідно ускладнює процес налагодження зворотного зв’язку у формі традиційного контролю й обумовлює необхідність застосування інформаційно-комунікативних технологій дистанційного навчання.

Інформаційно-комунікаційні технології дистанційного навчання - технології створення, накопичення, зберігання та доступу до веб-ресурсів (електронних ресурсів) навчальних дисциплін (програм), а також забезпечення організації та супроводу навчального процесу за допомогою спеціалізованого програмного забезпечення та засобів інформаційно-комунікаційного зв'язку, у тому числі Інтернету (Наказ МОН України від 25 квітня 2013 р. №466).

Наступною особливістю підготовки лікарів-інтернів є власне особистість дорослих учнів. Адже, у порівнянні з іншими, немедичними спеціальностями, особи, які є дипломованими фахівця- 
ми, починають самостійну практичну діяльність у якості молодих фахівців одразу після завершення додипломного курсу навчання в університеті, у той час, як лікарі, продовжують здобувати освіту на обов’язковому післядипломному етапі.

Саме тому, при організації навчання з лікарямиінтернами, які є дорослими учнями ми маємо враховувати такі андрагогічні особливості (Сисоєва С. О., 2011, с. 30), як:

- усвідомлення себе самостійною, самокерованою особистістю;

- накопичений життєвий досвід;

- $\quad$ готовність до навчання, що обумовлюється мотивацією до досягнення конкретної мети за допомогою освіти;

- прагнення до швидкої реалізації отриманих знань, умінь і навичок;

- обмеженість навчальної діяльності у часі через певні просторові, побутові, професійні та соціальні фактори.

3 огляду на зазначені особливості, налагодження системи контролю має бути здійснене у формі, що найменше обмежуватиме мобільність інтернів і не порушуватиме їх самосприйняття у якості самостійної та самокерованої особистості.

У цьому контексті, нашу увагу привернула можливість застосування ігрових комп'ютерних платформ для налагодження зворотного зв'язку, проведення проміжного оцінювання засвоєних знань, а також створення підгрунття для дискусії.

Сьогодні існує ряд он-лайн платформ для створення тестів, такі як: «Google Forms», «Quizlet, Proprofs», «Kahoot!», «Classmarker», «Plickers», «Easy Test Maker» тощо. Частина із яких є безкоштовними, інші мають повні передплатні версії та базові доступні без оплати.

Нашу увагу привернув безкоштовний сервіс «Kahoot!» - програма, що забезпечує можливість створення он-лайн тестів, опитувань і вікторин та може бути застосована у дидактичних цілях. Особливістю означеного сервісу є те, що приєднатися до нього можна з будь-якого пристрою, що має доступ до Інтернету без попереднього завантаження програмного забезпечення. Так, для участі у тестуванні учень має лише ввести на своєму пристрої PIN-код, що є унікальним для кожного тесту (Make learning awesome) і може розпочинати роботу.

На пристрої учасника варіанти відповідей відображатимуться у вигляді різнокольорових геометричних фігур, статичних для кожного з тестів, що оптимізує візуалізацію тестової інформації, представленої на материнському комп'ютері / екрані для кращого їі сприйняття та мінімізації технічних помилок при виборі відповіді.
На комп’ютері викладача, з якого було зроблено вхід у аккаунт, що є материнським для даного тесту, відображатимуться результати опитування окремо для кожного запитання та у цілому по групі запитань із зазначенням кількості респондентів і розподілу відповідей у відносних та абсолютних показниках.

Серед додаткових можливостей означеного ресурсу є необмежена чисельність учасників, опція часових обмежень, впродовж яких може бути надано відповідь, а також уведення балів за кожну 3 правильних відповідей, окрім цього програма підтримує можливість створення ілюстрованих та відеозапитань.

Для початку роботи з зазначеним сервісом викладачу необхідно зареєструватися, створивши свій аккаунт у якому у подальшому будуть створюватися тести, опитування та презентації матеріалів для дискусій.

Ще однією перевагою означеного сервісу є можливість коректування існуючих завдань, що значною мірою раціоналізує часові витрати викладача при підготовці до занять.

На нашу думку, застосування означеного ресурсу сприятиме ефективному налагодженню зворотного зв'язку у формі контролю із урахуванням структурних особливостей системи післядипломної підготовки лікарів, зокрема її практичної спрямованості, особистості дорослого учня, а також черговості очної та заочної частин навчання із відповідною зміною місця їх проходження 3 вищого медичного навчального закладу на заклад практичної охорони здоров'я.

Висновок. Однією з необхідних умов ефективного функціонування системи післядипломної підготовки лікарів є налагодження зворотного зв'язку між усіма учасниками навчального процесу. Зокрема, шляхом реалізації контролю, як виду зворотного зв’язку, що спрямований на перевірку відповідності фактичного рівня знань та практичних навичок лікарів-інтернів установленим вимогам. 3 метою забезпечення належної організації контролю, як форми зворотного зв'язку необхідно врахувати особливості структури післядипломної підготовки лікарів, зокрема їі практичну спрямованість, черговість очної та заочної частин навчання, а також андрагогічні характеристики особистості дорослого учня. У цьому контексті актуальною постає необхідність застосування інформаційно-комунікативних технологій дистанційного навчання, зокрема ігрових комп'ютерних платформ для налагодження зворотного зв'язку, проведення проміжного оцінювання засвоєних знань, а також створення підгрунття для дискусії.

\section{Література}

1. Зварич І. Проблема удосконалення контролю і оцінки знань студентів / І. Зварич // Рідна школа. 2000.- №10. - С. 43-45.

2. Минцберг Г. Структура в кулаке: создание эффективной организации / Пер. с англ. под ред. Ю. Н. Каптуревского. - СПб.: Питер, 2004. - 512 с. 
3. Наказ Міністерства освіти і науки України від 25.04.2013 р. №466 «Про затвердження Положення про дистанційне навчання» [Електронний ресурс]. - Режим доступу: http://zakon0.rada.gov.ua/laws/show/ z0703-13

4. Наказ Міністерства охорони здоров’я України від 19.09.1996 р. №291 «Про затвердження Положення про спеціалізацію (інтернатуру) випускників вищих медичних і фармацевтичних навчальних закладів освіти III-IV рівня акредитації медичних факультетів університетів» [Електронний ресурс]. - Режим доступу: http://zakon0.rada.gov.ua/laws/show/z0696-96

5. Основи теорії комунікації: Підручник / За ред. проф. М. А. Василика. - М.: Гардарики, 2006. - 615 с

6. Савченко О. Контроль та оцінка результатів навчання / О. Савченко. - К.: Абрис, 1997. C. $122-137$.

7. Сисоєва С. О. Інтерактивні технології навчання дорослих: навчальний посібник / С. О. Сисоєва. К.: ВД «Екмо», 2011. - 324 с.

8. Тэйлор Ф. Основы научного менеджмента. - М., 1992.

9. Make learning awesome [Electronic resource]. - Access mode : https://getkahoot.com/

\section{ИГРОВЫЕ КОМПЬЮТЕРНЫЕ ПЛАТФОРМЫ КАК СРЕДСТВО КОНТРОЛЯ В ПРОЦЕССЕ ПОДГОТОВКИ ВРАЧЕЙ-ИНТЕРНОВ}

Лысенко Александра, кандидат педагогических наук, заместитель директора Института последипломного образования, Национальный медицинский университет имени А. А. Богомольца, бульвар Т. Шевченко, 13, 01601 г. Киев, Украина, A.Yu.Lysenko@gmail.com

В предлагаемой статье рассмотрена необходимость осуществления контроля, как формы обратной связи на последипломном этапе подготовки врачей; определены особенности, присущие последипломному этапу подготовки врачей, которые должны быть учтены при обеспечении надлежащего контроля; описана необходимость применения информационно-коммуникативных технологий дистанционного обучения, в том числе игровых компьютерных платформ для налаживания обратной связи, проведения промежуточного оценивания усвоенных знаний, а также создание почвы для дискуссии.

Ключевые слова: игровые компьютерные платформы; информационно-коммуникативные технологии; обратная связь.

\section{PLAYING COMPUTER PLATFORM AS MEANS OF CONTROL IN THE MEDICAL INTERNS' PREPARATION PROCESS}

Oleksandra Lysenko, candidate of pedagogical sciences, Deputy Director of the Institute of Postgraduate Education, Bogomolets National Medical University, blvd. T. Shevchenka, 13, 01601 Kyiv, Ukraine,

A.Yu.Lysenko@gmail.com

This article highlights the necessity of control as a feedback form, which aims to verify compliance with the actual level of knowledge and practical skills of interns to set requirements for postgraduate stage of preparation; defines the features inherent in postgraduate stage of doctors training to be taken into account to ensure proper control, including its practical orientation, order full-time and part-time part of the training and andragogical characteristics of the individual adult learner (awareness of self independents, self-managed individual, accumulated experience, readiness to study, which is due to the motivation to achieve specific goals through education, commitment to rapid implementation of the acquired knowledge and skills, limited training activities over time at regular spatial, personal, professional and social factors); identifies the need of information and communication technologies usage for distance learning, particularly as those which least restrict the mobility of interns and not violate their self-perception as independent and self-governing individual, including through the use of computer gaming platforms, such as «Google Forms», «Quizlet, Proprofs», «Kahoot!», «Classmarker», «Plickers», «Easy Test Maker» to establish a feedback of the interim evaluation of learning, and creating a basis for discussion control with regard to structural features of postgraduate doctors' training.

Keywords: computer gaming platform; feedback; information and communication technology.

Стаття надійшла до редакції 23.09.2016

Прийнято до друку 27.10.2016 